\title{
A Principal Component Analysis (PCA) Approach to Seasonal and Zooplankton Diversity Relationships in Fishing Grounds of Mannar Gulf, India
}

\author{
J. Selvin PITCHAIKANI ${ }^{1 *}$, A.P. LIPTON ${ }^{2}$ \\ ${ }^{I}$ Manonmaniam Sundaranar University, Centre for Marine Science and Technology, Rajakkamangalam, Tamil Nadu, \\ India; selvinocean@gmail.com (*correspondingauthor) \\ ${ }^{2}$ Central Marine Fisheries Research Institute, Vizhinjam, Kerala, India; liptova@yahoo.co.in
}

\begin{abstract}
Principal component analysis (PCA) is a technique used to emphasize variation and bring out strong patterns in a dataset. It is often used to make data easy to explore and visualize. The primary objective of the present study was to record information of zooplankton diversity in a systematic way and to study the variability and relationships among seasons prevailed in Gulf of Mannar. The PCA for the zooplankton seasonal diversity was investigated using the four seasonal datasets to understand the statistical significance among the four seasons. Two different principal components (PC) were segregated in all the seasons homogeneously. PCA analyses revealed that Temora turbinata is an opportunistic species and zooplankton diversity was significantly different from season to season and principally, the zooplankton abundance and its dynamics in Gulf of Mannar is structured by seasonal current patterns. The factor loadings of zooplankton for different seasons in Tiruchendur coastal water (GOM) is different compared with the Southwest coast of India; particularly, routine and opportunistic species were found within the positive and negative factors. The copepods Acrocalanus gracilis and Acartia erythrea were dominant in summer and Southwest monsoon due to the rainfall and freshwater discharge during the summer season; however, these species were replaced by Temora turbinata during Northeast monsoon season.
\end{abstract}

Keywords: Gulf of Mannar, principal component analysis, Tiruchendur and copepods, zooplankton diversity

\section{Introduction}

Zooplankton inhabits oceans at all the depths and occupies every ecological niche that is considered as the chief index of utilizing aquatic biotope at the secondary trophic level (Pitchaikani and Lipton, 2015). Sea surface temperature, salinity and inorganic nutrients are some of the important factors that are reported to cause spatial changes among zooplankton population (Lawrence et al., 2004). Among the zooplankton groups, copepods are the important grazers of phytoplankton and micro zooplankton, and hence they form a major trophic link to many predatory invertebrates and fish (Atkinson, 1996). Studies related to seasonal variation and zooplankton diversity in offshore waters, particularly in fishing grounds of Gulf of Mannar, is meager; hence, the present study was established to investigate the relationship between seasons and zooplankton diversity.

Pelagic copepods are a key trophic group in the marine plankton, where they play important roles in both the transfer of energy from primary producers to higher trophic levels and biogeochemical cycles (Roemmich et al., 1995;
Beaugrand et al., 2009). Principal component analysis (PCA) is a technique used to emphasize variation and bring out strong patterns in a dataset. It is often used to make data easy to explore and visualize. The primary objective of the present study was to record information of zooplankton diversity in a systematic way and to study the variability and relationships among seasons prevailed, which in turn should be useful for an understanding of highly variable aquatic environments in general, besides Gulf of Mannar.

\section{Materials and Methods}

The present investigations of principal component analyses (PCA) on zooplankton diversity was carried out and in the coastal waters off Tiruchendur, Southeast coast of Tamil Nadu (Gulf of Mannar), India. The study was carried out at three different fishing grounds (Fig. 1): Station-1 (Lat: $8^{\circ} .27^{\prime} .28 .48^{\prime \prime N}$, Long: $78^{\circ} .8^{\prime} .18 .48^{\prime \prime} \mathrm{E}$ ), Station-2 (Lat: $8^{\circ} .27^{\prime} .23 .32^{\prime \prime} \mathrm{N}$ and Long: $78^{\circ} .14^{\prime} .57 .06^{\prime \prime} \mathrm{E}$ ), Station-3 (Lat: $8^{\circ} .30^{\prime} .46 .2^{\prime \prime} \mathrm{N}$ and Long: $78^{\circ} .16^{\prime} .48 .15^{\prime \prime} \mathrm{E}$ ), for a period of two years, extending from January 2009 to December 2010. The area located between the Southeast coast of India and West coast of Sri Lanka is a unique 
154

marine environment, and rich in biodiversity (Pitchaikani and Lipton, 2015).

The zooplankton diversity data used in the present study was obtained from the published data of the first author of this paper (Pitchaikani and Lipton, 2015). To examine the relationship among the four seasonal data sets, Principal Component Analyses (PCA) was performed on the zooplankton species diversity using program PAST ver. 2.01 (Hammer, 2001). This program makes PCA of the correlation matrix of two sets of data (environmental data and zooplankton counts) and also calculates the correlations between the components of the two sets.

\section{Results and Discussion}

A total of 49 species of zooplankton have been recorded during the study. The PCA for the zooplankton seasonal diversity was investigated using the four seasonal datasets to understand the statistical significance among the four seasons viz. post monsoon (January-March), summer season (April-June), southwest monsoon (July-September) and northeast monsoon (October-December). Two different principal components (PC) were segregated in all the seasons homogeneously. The component matrix which is exceeding 0.6 could be taken for interpretation in the present study (Udayakumar et al., 2009; Jose et al., 2012).
The correlation matrix loadings of the significant principal components for the four seasons are given in Tables 1 to 4 .

For a few coastal areas, it has been suggested that protists occasionally constitute the main food source for calanoid and cyclopoid copepods (Kleppel et al., 1991; Pierce et al., 1992; Levinsen et al., 2000), which would have important implications for food web dynamics. In order to provide an insight into this idea, the present study was aimed to attempt statistically the feeding of small copepods on the full food size-spectrum (phytoplankton) and predation on juvenile appendicularians.

\section{Principal component analyses (PCA)}

In the post monsoon season, two different components of the principal component analyses explained 100\% of total variance with eigene values exceeding 1 as could be boted from Table 1. The total variance observed in the study was directly linked with zooplankton forage predicting the routine $(\mathrm{PC} 1)$ and opportunistic grazers (PC2). The extracted principal component 1 (PC1) explained $74.9 \%$ of the total variability and this could be used to differentiate the zooplankton groups present within the extracted fishing grounds. Earlier studies also emphasized similar findings in Gulf of Manine (Pershing et al., 2005).

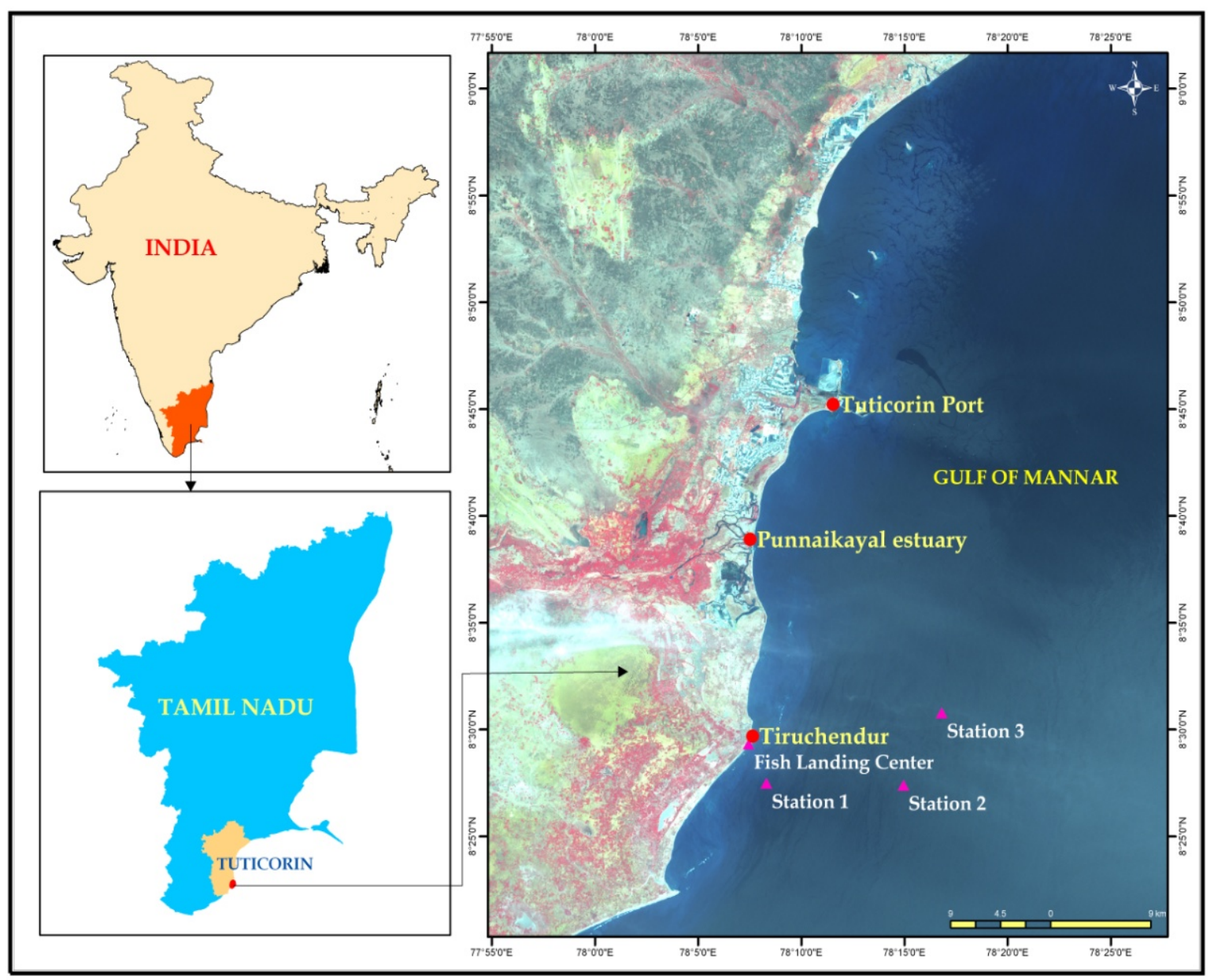

Fig. 1. Study area, Tiruchendur, Southeast coast of Tamil Nadu, Gulf of Mannar 
Table 1. Eigene analyses of the correlation matrix loadings of the significant principal components in post-monsoon season

\begin{tabular}{|c|c|c|c|c|c|}
\hline \multicolumn{3}{|c|}{ significant principal components in post-monsoon season } & \multirow{2}{*}{$\begin{array}{l}\text { Nauplius of balanus } \\
\text { Cypris of balanus }\end{array}$} & \multirow{2}{*}{$\begin{array}{l}0.9688 \\
0.5444\end{array}$} & \multirow{2}{*}{$\begin{array}{l}-0.2479 \\
-0.8388\end{array}$} \\
\hline Post monsoon season & PCA 1 & PCA 2 & & & \\
\hline Eigene values & 9.11943 & 3.05 & \multirow[t]{3}{*}{ Globigerina spp } & -0.9996 & \multirow[t]{3}{*}{0.02752} \\
\hline Variability (\%) & 74.924 & 25.08 & & & \\
\hline Cumulative \% & 74.924 & 100 & & & \\
\hline \multicolumn{3}{|l|}{ Factor loadings } & \multirow{2}{*}{\multicolumn{3}{|c|}{$\begin{array}{l}\text { Table } 2 \text {. Eigene analyses of the correlation matrix loadings of the } \\
\text { significant principal components in summer }\end{array}$}} \\
\hline Acartia erythrea & 0.8992 & -0.4376 & & & \\
\hline Acartia spinicauda & 0.6569 & -0.754 & Summer & PCA 1 & PCA 2 \\
\hline Acrocalanus gibber & -0.93 & 0.3676 & Eigene values & 4.76 & 0.90 \\
\hline Acrocalanus gracilis & -0.9352 & 0.354 & Variability (\%) & 84.18 & 15.82 \\
\hline Eucalanus elongates & -0.7085 & 0.7057 & Cumulative \% & 84.18 & 100 \\
\hline Eucalanus subcrassus & -0.9194 & 0.3934 & Factor loadings & & \\
\hline Paracalanusparvus & 0.947 & -0.3213 & Acartia erythrea & 0.9812 & -0.1932 \\
\hline Paracalanus simplex & 0.9806 & 0.1959 & Acartia spinicauda & 0.9883 & -0.1526 \\
\hline Calanopia elliptica & 0.8666 & -0.499 & Acrocalanus gibber & -0.7704 & 0.6375 \\
\hline Temora turbinate & 0.6814 & 0.7319 & Acrocalanus gracilis & -0.7379 & 0.6749 \\
\hline Copepodite labidoceropavo & 0.5965 & -0.8026 & Eucalanus elongatus & -0.4334 & 0.9012 \\
\hline Oncaea venusta & 0.8782 & 0.4782 & Eucalanus subcrassus & -0.421 & 0.9071 \\
\hline Oncaea conifera & -0.9224 & 0.3863 & Paracalanusparvus & 0.989 & 0.1477 \\
\hline Clausocalanus arcuicornis & -0.9901 & -0.1402 & Paracalanus simplex & 0.8955 & 0.4452 \\
\hline Nannocalanusminor & 0.5221 & -0.8529 & Calanopia elliptica & 0.8096 & -0.587 \\
\hline Pseudodiaptomussp. & 0.5877 & -0.8091 & Temora turbinata & -0.3788 & 0.9255 \\
\hline Metacalanus aurivillii & -0.9879 & 0.1553 & Copepodite labidoceropavo & 0.9227 & -0.3855 \\
\hline Metacalanussp. & -0.3739 & 0.9275 & Oncaea venusta & 0.9919 & 0.1266 \\
\hline Temora discaudata & -0.3466 & 0.938 & Oncaea conifera & -0.8506 & 0.5258 \\
\hline Temora stylifera & 0.8024 & -0.5968 & Clausocalanus arcuicornis & -0.6187 & 0.7856 \\
\hline Calanopia minor & 0.9643 & -0.2648 & Nannocalanus minor & -0.9603 & 0.279 \\
\hline Euchaeta marina & 0.1402 & -0.9901 & Pseudodiaptomus sp. & 0.9883 & -0.1526 \\
\hline Euterpina acutiferons & 0.999 & 0.04473 & Metacalanus aurivillii & -0.7796 & 0.6263 \\
\hline Oithona brevicornis & 0.2083 & -0.9781 & Metacalanussp. & -0.9765 & 0.2155 \\
\hline Oithona rigida & 0.9848 & 0.1737 & Temora discaudata & -0.4266 & 0.9044 \\
\hline Oithona similis & -0.9958 & -0.0911 & Temora stylifera & 0.9417 & -0.3366 \\
\hline Oithona nana & -0.8252 & 0.5649 & Calanopiaminor & 0.5971 & -0.8022 \\
\hline Oithona spinirostris & 0.9434 & 0.3315 & Euchaeta marina & -0.9131 & -0.4077 \\
\hline Corycaeussp. & 0.3736 & 0.9276 & Euterpina acutiferons & 0.8675 & 0.4974 \\
\hline Corycaeus danae & 0.03712 & -0.9993 & Oithona brevicornis & -.07791 & -0.997 \\
\hline Favella brevis & 0.9024 & -0.4309 & Oithona rigida & 0.06002 & -0.9982 \\
\hline Tintinnopsis cylindrica & -0.7874 & -0.6165 & Oithona similis & -0.9812 & 0.1932 \\
\hline Tintinnopsis cynensis & 0.8403 & -0.5422 & Oithona nana & 0.7856 & 0.6187 \\
\hline Sagita enflata & -0.9368 & 0.3499 & Oithona spinirostris & 0.8608 & 0.5089 \\
\hline Lucifersp. & -0.2493 & 0.9684 & Corycaeussp. & 0.1963 & 0.9806 \\
\hline Gastropod larvae & 0.8227 & 0.5685 & Corycaeus danae & 0.5658 & -0.8245 \\
\hline Gastropod veliger & 0.9733 & 0.2295 & Favella brevis & 0.9995 & -.03129 \\
\hline Bivalve veliger & -0.8107 & 0.5855 & Tintinnopsis cylindrica & -0.9227 & 0.3855 \\
\hline Crabzoea & 0.5648 & -0.8252 & Tintinnopsis cynensis & 0.07086 & -0.9975 \\
\hline Euphasid zoea & 0.882 & -0.4713 & Sagita enflata & -0.7292 & 0.6843 \\
\hline Labidocera acuta & 0.5258 & -0.8506 & Lucifer sp. & 0.7289 & 0.6847 \\
\hline Leucosiidae zoea & 0.4646 & -0.8855 & Gastropod larvae & 0.7623 & 0.6472 \\
\hline Porcellidium spp. & 0.8532 & 0.5216 & Gastropod veliger & 0.9993 & 0.03696 \\
\hline Portunidae spp. & -0.6165 & 0.7874 & Bivalve veliger & 0.5415 & 0.8407 \\
\hline Dotilla fenestrate & 0.9979 & 0.06547 & Crabzoea & 0.889 & -0.458 \\
\hline
\end{tabular}




\begin{tabular}{lcc}
\hline Euphasid zoea & 0.05175 & -0.9987 \\
\hline Labidocera acuta & -0.5243 & -0.8515 \\
\hline Leucosiidae zoea & -0.9322 & -0.362 \\
\hline Porcellidium spp. & 0.9985 & 0.05463 \\
\hline Portunidaespp. & -0.7623 & -0.6472 \\
\hline Dotillafenestrate & 0.491 & 0.8711 \\
\hline Mysis larvae & 0.08929 & -0.996 \\
\hline Nauplius of balanus & 0.9691 & -0.2465 \\
\hline Cypris of balanus & -0.3044 & -0.9525 \\
\hline Globigerina spp. & 0.3666 & 0.9304 \\
\hline
\end{tabular}

In the $\mathrm{PC} 1$ of the post monsoon, species such as Acartia erythrea, A. spinicauda, Paracalanus parvus, P. simplex, Calanopia elliptica, Temora turbinata, Oncaea venusta, $T$. stylifera, Calanopia minor, Euterpina acutiferons, Oithona rigida, O. spinirostris, Favella brevis, Tintinnopsis cynensis, Gastropod larvae, Gastropod veliger, Euphasid zoea, Porcellidium spp., Dotilla fenestrate and Nauplius of balanus were showed with positive significant correlation, which indicated their preference for sharing the same feeding habitat devoid of antagonism as suggested by Jose et al. (2012). However, the positive loadings in the PC1, most of the copepods species were herbivores, except that of Oithona rigida and $O$. spinirostris as similarly reported by Madupradap et al. (2003). Carnivore species also congregated in the same ground along with herbivores though they limit their feeding habit. This result therefore suggests that different feeding habituated zooplankton species gathered in the fishing grounds during the post monsoon season.

However, the PC1 components showed negative correlation with Acrocalanus gibber, A. gracilis, Eucalanus elongatus, E. subcrassus, Oncaea conifer, Clausocalanus arcuicornis, Metacalanus aurivillii, Oithona similis, O. nana, Tintinnopsis cylindrical, Sagita enflata, Bivalve veliger, Portunidae spp. and Globigerina spp. It was thus clearly noticed that, the significant positive loading species of copepods, which were also dominant exerted grazing pressure, which in turn depressed the remaining copepods by the way of squeezing them away from their feeding grounds (Jose et al., 2012). However, during the post monsoon season, most of the copepods remain there and only a few opportunistic species invade the fishing grounds with respect to the seasonal current pattern, as well as grazing pressure. In the Arabian Sea, upwelling and down welling are the prime factors that control the invading species along with grazing pressure. But in the case of Gulf of Mannar, seasonal current patterns are playing a major role on zooplankton species abundance (Jagadeesan et al., 2013).

The results of the present study clearly demonstrated the following species as opportunistic invaders: Acartia erythrea, Paracalanus simplex, Temora turbinate, Clausocalanus arcuicornis, Metacalanus aurivillii, Calanopia minor, Euchaeta marina, Euterpina acutiferons, Oithona nana, $O$. spinirostris, Crab zoea, Globigerina spp. These opportunistic invaders could have possibly entered from northern part of the Gulf of Mannar and Palk Bay due to the monsoon induced water circulation pattern. From the PCA analyses, results reinforced the idea that the zooplanktonic community of Gulf of Mannar could be strongly influenced by hydrological circulation patterns. Similar inference could be noted from earlier studies in Gulf of Mannar and in Gulf of Maine (Pershing et al., 2005). The results of the present study thus agreed with findings in other regions and explained that copepods constituted the major taxa in Catalan Sea (Jyothibabu et al., 2013), in Arabian Sea (Madhupratap et al., 2001; Jose et al., 2012), and in Mondego estuary (Marques et al., 2007).

PC2 represented the following species viz. Eucalanus elongatus, Temora turbinata, Metacalanus sp., Temora discaudata, Corycaeus sp., Corycaeus sp., Lucifer sp., Portunidae spp., with positive significant correlation. Most of the species were herbivores and preferred to grazing phytoplankton. Thus the PCA analyses tend to conclude that Portunidae spp. was the only opportunistic species available during the post monsoon season. This may be due to the coastal water circulation pattern in Gulf of Mannar. Increased abundance of both herbivores and carnivores in the fishing grounds could thus lead to sequential community development, subsequent to the start of nutrient supply either by current pattern or upwelling as recorded by Madhupratap and Haridas (1990).

However, the following species viz. Acartia spinicauda, Copepodite labidoceropavo, Nannocalanus minor, Pseudodiaptomus sp., Euchaeta marina, Oithona brevicornis, Corycaeus danae, Tintinnopsis cylindrical, Crab zoea, Labidocera acuta, Lencosiidae zoea, Mysis larvae, Cypris of balanus were negatively correlated at significant level due to the grazing pressure from the positive significant zooplankton groups, suppressing the species of negatively significant zooplankon species by the way of dragging away from their feeding ground (Jose et al., 2012).

In the summer season also, PCA separated two different principal components explained $100 \%$ of total variance with eigene values exceeding 1 (Table 2). The extracted principal component 1 (PC1) explained $84.18 \%$ of the total variability and PC2 explained about $15.82 \%$ of variability. The following species viz. Acartia erythrea, A. spinicauda, Paracalanus simplex, Calanopia elliptica, Copepodite labidoceropavo, Oncaea venusta, Pseudodiaptomus sp., Temora stylifera, Euterpina acutiferons, Oithona nana, $O$. spinirostris, Favella brevis, Lucifer sp., Gastropod larvae, Gastropod veliger, Crab zoea, Porcellidium spp. and Nauplius of balanus showed positive significant correlation.

Similar to the post monsoon season, the herbivores and carnivores zooplankton species were abundantly observed in PC1 during summer season. Among the recorded zooplankton, the herbivores dominated in terms of biomass, which suggested that the richest areas of zooplankton production in turn are associated with areas of high primary productivity (Padmakumar et al., 2010). In PC1, the following species identified as opportunistic species, invaded the fishing grounds based on the seasonal current pattern and grazing pressure: Acartia erythrea, Paracalanus simplex, Oncaea venusta, Temora turbinata, T. stylifera, Clausocalanus arcuicornis, Favella brevis, Tintinnopsis cynensis, Metacalanus aurivillii, Calanopia minor, Labidocera acuta, Euchaeta marina, Porcellidium spp., 
Table 3. Eigene analyses of the correlation matrix loadings of the significant principal components in SW monsoon

\begin{tabular}{|c|c|c|}
\hline SW monsoon & PC1 & PC2 \\
\hline Eigene values & 4.83531 & 1.66589 \\
\hline Variability (\%) & 74.376 & 25.624 \\
\hline Cumulative \% & 74.376 & 100 \\
\hline \multicolumn{3}{|l|}{ Factor loadings } \\
\hline Acartia erytbrea & 0.8365 & -0.5479 \\
\hline Acartia spinicauda & 0.9755 & 0.2201 \\
\hline Acrocalanus gibber & -0.7782 & 0.6281 \\
\hline Acrocalanus gracilis & -0.6003 & 0.7998 \\
\hline Eucalanus elongatus & -0.3332 & 0.9429 \\
\hline Eucalanus subcrassus & -0.7529 & 0.6582 \\
\hline Paracalanusparvus & 0.8582 & -0.5134 \\
\hline Paracalanus simplex & 0.9241 & -0.3822 \\
\hline Calanopia elliptica & -0.279 & 0.9603 \\
\hline Temora turbinate & -0.2642 & 0.9645 \\
\hline Copepodite labidoceropavo & 0.9985 & -0.0542 \\
\hline Oncaea venusta & 0.9825 & 0.1861 \\
\hline Oncaea conifera & -0.9917 & 0.1287 \\
\hline Clausocalanus arcuicornis & -0.7442 & 0.6679 \\
\hline Nannocalanusminor & -0.7632 & 0.6461 \\
\hline Pseudodiaptomus sp. & -0.1951 & 0.9808 \\
\hline Metacalanus aurivillii & -0.0062 & 1 \\
\hline Metacalanussp. & -0.0845 & -0.9964 \\
\hline Temora discaudata & 0.5021 & 0.8648 \\
\hline Temora stylifera & 0.9052 & 0.4249 \\
\hline Calanopia minor & 0.7217 & -0.6922 \\
\hline Euchaeta marina & -0.2101 & -0.9777 \\
\hline Euterpina acutiferons & 0.7297 & 0.6838 \\
\hline Oithona brevicornis & -0.0845 & -0.9964 \\
\hline Oithona rigida & -0.3491 & 0.9371 \\
\hline Oithona similis & -0.6673 & 0.7448 \\
\hline Oithona nana & 0.966 & 0.2586 \\
\hline Oithona spinirostris & 0.8213 & 0.5705 \\
\hline Corycaeus sp. & -0.215 & 0.9766 \\
\hline Corycaeus danae & 0.3587 & -0.9335 \\
\hline Favella brevis & 0.793 & -0.6092 \\
\hline Tintinnopsis cylindrica & 0.6436 & 0.7654 \\
\hline Tintinnopsis cynensis & 0.394 & -0.9191 \\
\hline Sagita enflata & -0.8228 & 0.5683 \\
\hline Lucifer sp. & 0.1064 & 0.9943 \\
\hline Gastropod larvae & 0.9808 & 0.1951 \\
\hline Gastropod veliger & 0.9944 & 0.1052 \\
\hline Bivalve veliger & -0.6772 & 0.7358 \\
\hline Crabzoea & 0.9711 & -0.2386 \\
\hline Euphasidzoea & -0.9801 & 0.1983 \\
\hline Labidocera acuta & -0.2714 & -0.9625 \\
\hline Leucosiidae zoea & -0.3969 & -0.9179 \\
\hline Porcellidium spp. & 0.9223 & 0.3866 \\
\hline Portunidae spp. & -0.6793 & -0.7339 \\
\hline Dotilla fenestrate & 0.6487 & -0.7611 \\
\hline
\end{tabular}

\begin{tabular}{lcc} 
Mysis larvae & -0.0845 & -0.9964 \\
Nauplius of balanus & 0.599 & 0.8008 \\
\hline Cypris of balanus & 0.4249 & -0.9052 \\
Globigerina spp. & -0.9237 & -0.3831 \\
\hline
\end{tabular}

Euterpina acutiferons, Crab zoea, Portunidae spp., Globigerina spp., Mysis larvae and Cypris of balanus. While comparing post monsoon, more opportunistic species have invaded the fishing area in the summer season, due to the favorable environmental conditions such as salinity, sea surface temperature and coastal current pattern along the western boundary of Gulf of Mannar. Most of the studies on zooplankton in the Indian coastal waters with respect to the physical oceanographic factors mostly limited to the upwelling and eddies (Madhupratap, 1987; Jagadeesan et al., 2013).

The positively correlated PC1 species showed negative correlation with Acrocalanus gibber, A. gracilis, Oncaea conifer, Clausocalanus arcuicornis, Nannocalanus minor, Metacalanus aurivillii, Metacalanus sp., Euchaeta marina, Oithona similis, Tintinnopsis cylindrical, Sagita enflata, Leucosiidae zoea, Portunidae spp. Among these, M. aurivillii, Euchaeta marina and Portunidae spp. were identified as opportunistic species.

In summer season, PC2 represented the following species viz. Acrocalanus gibber, Acrocalanus gracilis, Eucalanus elongatus, E. subcrassus, Temora turbinate, Clausocalanus arcuicornis, Metacalanus aurivillii, Temora discaudata, Oithona nana, Corycaeus sp., Sagita enflata, Lucifer sp., Gastropod larvae, Bivalve veliger, Dotilla fenestrata and Globigerina spp., with significant positive correlation. Among these positive groups, the following species identified as opportunistic species: Temora turbinata, Clausocalanus arcuicornis, Metacalanus aurivillii, Oithona nana, Globigerina spp., while the rest of the species could be grouped as routine ones, being uniformly abundant throughout the year. From the factor analyses, it was derived that the grazing power of zooplankton on phytoplankton was in balanced condition (Verity and Smetacek, 1996) and development of algal bloom could be controlled by zooplankton. Since the grazing power of zooplankton over phytoplankton was in a balanced state, there was no algal bloom in the study area.

The second component of $\mathrm{PC} 2$ represented the routine and opportunistic groups. The routine group included species such as Calanopia minor, Oithona brevicornis, $O$. rigida, Euphasid zoea and Cypris of balanus. The grazing zooplanktons of opportunistic invaded species including herbivores and carnivores viz. Tintinnopsis cynensis, Labidocera acuta, Portunidae spp. and Mysis larvae.

In the southwest monsoon also, two different principal components PC1 and PC2 (Table 3) were extracted consisting $74.3 \%$ and $25.6 \%$ variability with eigene values exceeding 1 . The first component showed strong positive loading on all Acartia erythrea, A. spinicauda, Paracalanus parvus, P. simplex, Copepodite labidoceropavo, Oncaea venusta, Temora stylifera, Calanopia minor, Euterpina acutiferons, Oithona nana, O. spinirostris, Favella brevis, Tintinnopsis cylindrical, Gastropod larvae, Gastropod veliger, 
158

Crab zoea, Porcellidium spp. and Dotilla fenestrate. Most of the species were herbivores except Oithona nana, $O$. spinirostris and Porcellidium spp. Similar to the post

Table 4. Eigene analyses of the correlation matrix loadings of the significant principal components in NE monsoon

\begin{tabular}{|c|c|c|}
\hline NE monsoon & PC1 & PC 2 \\
\hline Eigene values & 5.67044 & 0.784322 \\
\hline Variability (\%) & 87.849 & 12.151 \\
\hline Cumulative \% & 87.849 & 100 \\
\hline \multicolumn{3}{|l|}{ Factor loadings } \\
\hline Acartia erythrea & -0.2457 & -0.9693 \\
\hline Acartia spinicauda & 0.7644 & -0.6448 \\
\hline Acrocalanus gibber & -0.6647 & 0.7472 \\
\hline Acrocalanus gracilis & -0.8181 & -0.5751 \\
\hline Eucalanus elongatus & -0.5177 & 0.8555 \\
\hline Eucalanus subcrassus & -0.3344 & 0.9424 \\
\hline Paracalanus parvus & -0.5404 & 0.8414 \\
\hline Paracalanus simplex & 0.786 & -0.6182 \\
\hline Calanopia elliptica & 0.9284 & 0.3716 \\
\hline Temora turbinate & -0.0883 & 0.9961 \\
\hline Copepodite labidoceropavo & 0.119 & -0.9929 \\
\hline Oncaea venusta & 0.9958 & -0.09195 \\
\hline Oncaea conifera & -0.938 & 0.3466 \\
\hline Clausocalanus arcuicornis & -0.4809 & 0.8768 \\
\hline Nannocalanus minor & 0.2352 & -0.972 \\
\hline Pseudodiaptomussp. & 0.9009 & -0.4339 \\
\hline Metacalanus aurivillii & 0.786 & -0.6182 \\
\hline Metacalanussp. & -0.9905 & -0.1377 \\
\hline Temora discaudata & -0.3769 & 0.9263 \\
\hline Temora stylifera & 0.9774 & -0.2116 \\
\hline Calanopia minor & 0.4146 & -0.91 \\
\hline Euchaeta marina & -0.976 & 0.2179 \\
\hline Euterpina acutiferons & -0.5154 & 0.8569 \\
\hline Oithona brevicornis & -0.6431 & -0.7658 \\
\hline Oithona rigida & -0.6182 & -0.786 \\
\hline Oithona similis & -0.9115 & 0.4113 \\
\hline Oithona nana & 0.4585 & 0.8887 \\
\hline Oithona spinirostris & -0.8203 & 0.5719 \\
\hline Corycaeussp. & -0.2556 & 0.9668 \\
\hline Corycaeus danae & -0.9947 & -0.1029 \\
\hline Favella brevis & 0.676 & -0.7369 \\
\hline Tintinnopsis cylindrica & -0.602 & 0.7985 \\
\hline Tintinnopsis cynensis & -0.2823 & -0.9593 \\
\hline Sagita enflata & -0.5566 & 0.8308 \\
\hline Lucifersp. & 0.761 & 0.6487 \\
\hline Gastropod larvae & 0.9613 & 0.2756 \\
\hline Gastropodveliger & 0.7062 & -0.708 \\
\hline Bivalve veliger & -0.9964 & 0.0851 \\
\hline Crabzoea & -0.0802 & -0.9968 \\
\hline Euphasid zoea & -0.812 & -0.5837 \\
\hline Labidocera acuta & -0.4955 & 0.8686 \\
\hline Leucosiidae zoea & -0.9522 & -0.3055 \\
\hline
\end{tabular}

\begin{tabular}{lll} 
Porcellidium spp. & 0.9985 & 0.05517 \\
\hline Portunidae spp. & -0.6829 & -0.7305 \\
\hline Dotilla fenestrate & 0.9924 & 0.1232 \\
\hline Mysis larvae & -0.5226 & -0.8526 \\
\hline Nauplius of balanus & -0.883 & -0.4694 \\
\hline Cypris of balanus & -0.7658 & -0.643 \\
Globigerina spp. & -0.7266 & 0.687 \\
\hline
\end{tabular}

monsoon and summer, herbivore and carnivore groups were identified in the PC1 as positive loadings. Further, they were grouped as routine and opportunistic species. The routine group included $A$. erythrea, $A$. spinicauda, Copepodite labidoceropavo, Oncaea venusta, Temora stylifera, Euterpina acutiferons, O. nana, O. spinirostris, Favella brevis, Tintinnopsis cylindrical, Gastropod larvae, Gastropod veliger, Crab zoea, Porcellidium spp. and Dotilla fenestrate. The opportunistic group included Paracalanus simplex, Calanopia minor, $O$. nana and $O$. spinirostris. The opportunistic zooplankton observed during the southwest monsoon was similar with post monsoon species. Oithona was ubiquitous in the Gulf of Mannar, however, their large biological differences, in the community shift (eg. O. nana) had large proportional changes in their seasonal cycle. A similar trend was explained to occur along the Gulf of Maine (Pershing et al., 2005). During the southwest monsoon season, phytoplankton population density had decreased gradually evidently due to the least availability of a few phytoplankton species: many of the zooplankton species which foraged in the food-rich surface layers would have possibly migrated to deeper waters form a direct source of flux of organic matter into the ocean interiors (Madhupratap and Parulekar, 1993).

The PC2 showed significant positive correlation among copepods assemblage such as $A$. gibber, $A$. gracilis, $E$. elongates, E. subcrassus, Calanopia elliptica, Temora turbinate, Clausocalanus arcuicornis, Nannocalanus minor, Pseudodiaptomus sp., Metacalanus aurivilli, Temora discaudata, Euterpina acutiferons, O. rigida, O. similis, Corycaeus sp., Tintinnopsis cylindrical, Lucifer sp., Bivalve veliger and Nauplius of Balanus. Similar to the post monsoon season and summer season, herbivores and carnivores species were recorded in southwest monsoon as well. However, there was a sharp declining in Leucosiidae zoea, Porcellidium spp., Portunidae spp., Calanopia elliptica, Oithona nana, Calanopia elliptica and Sagita enflata in the fishing grounds. Particularly, temporal and spatial variation in Lucifer sp. abundance was noticed during the study. During the first year of study, density of Lucifer sp. showed slight declining trend in southwest monsoon, and Lucifer sp. was not observed at station 3, in the second year of the study. Jacob et al. (1981) reported sharp declining trend of Lucifer sp. during southwest monsoon season in Vizhinjam coastal waters.

In the PC2, the following strong negative correlation were noticed viz. Metacalanus sp., Calanopia minor, Euchaeta marina, Oithona brevicornis, Corycaeus danae, Favella brevis, Tintinnopsis cynensis, Labidocera acuta, Leucosiidae zoea, Portunidae spp., Dotilla fenestrate, Mysis larvae and Cypris of Balanus. 
In the northeast monsoon PC1 and PC2 (Table 4) were extracted with $87.8 \%$ and $12.1 \%$ variability with eigene values exceeding 1. PC1 species viz. Acartia erythrea, Acartia spinicauda, Acartia spinicauda, Calanopia elliptica, Oncaea venusta, Pseudodiaptomus sp., Metacalanus aurivillii, Temora stylifera, Favella brevis, Dotilla fenestrate were identified as opportunistic invader species, followed by Paracalanus simplex, Lucifer sp., Gastropod larvae, Gastropod veliger, Porcellidium spp. Similar to the summer season, herbivores and carnivores species were emerging together in northeast monsoon to share their food. The overall composition of copepods, harpacticoida and cyclopoida abundance were more or less the same throughout year in the fishing grounds of Gulf of Mannar. Similar findings were reported in Arabian Sea by Madhupratap et al. (2003). In the PC1, Acrocalanus gibber, Acrocalanus gracilis, Oncaea conifer, Metacalanus sp., Euchaeta marina, Oithona brevicornis, Oithona rigida, Oithona similis, Oithona spinirostris, Corycaeus danae, Tintinnopsis cylindrical, Bivalve veliger, Euphasid zoea, Leucosiidae zoea, Portunidae spp., Cypris of balanus and Globigerina spp. exhibited negative correlation. As implied by the principal component analyses, the routine species and opportunistic species were obliquely appearing in the study area as reported by Pershing et al. (2005).

The second component (PC2) of northeast monsoon showed strong positive loading on the species viz. Acrocalanus gibber, Eucalanus elongatus, Eucalanus subcrassus, Paracalanus parvus, Temora turbinate, Clausocalanus arcuicornis, Temora discaudata, Euterpina acutiferons, Oithona nana, Corycaeus sp., Tintinnopsis cylindrical, Sagita enflata, Lucifer sp., Labidocera acuta, Globigerina spp. and the negative correlations on the following species Acartia erythrea, Acartia spinicauda, Paracalanus simplex, Copepodite labidoceropavo, Nannocalanus minor, Metacalanus aurivillii, Calanopia minor, Oithona brevicornis, Oithona rigida, Favella brevis, Tintinnopsis cynensis, Gastropod veliger, Crab zoea, Portunidae spp., Mysis larvae, Cypris of balanus.

As implied by PCA, the zooplankton diversity was high in northeast monsoon. The factor loadings of zooplankton for different seasons in Tiruchendur coastal water (GOM) was differed from the study carried out by Jose et al. (2012) along the southwest coast of India, particularly, routine and opportunistic species were found within the positive and negative factors. The copepods Acrocalanus gracilis and Acartia erythrea were dominant in summer and southwest monsoon due to the rainfall and freshwater discharge during the summer season; however, these species were replaced by Temora turbinata during northeast monsoon season. The Temora turbinata was found abundantly during southwest monsoon and northeast monsoon. Temora turbinata is an important copepod group, which acts as indicator species of coastal upwelling. Jagadeesan et al. (2013) reported Temora turbinata in Gulf of Mannar (northern part) during the southwest monsoon only, but in the present study, this species was recorded during southwest monsoon and northeast monsoon as well.
From the results of PCA analyses, it was found that Temora turbinata is an opportunistic species, and also evidenced by Jagadeesan et al. (2013) in to northern Gulf of Mannar. Temora turbinata species showed positive loading during post monsoon only and this species did not show any significant loadings in other seasons. Further, Temora turbinata is capable of exploiting upwelling induced high phytoplankton stock prevailing along the west coast of India during the southwest monsoon (Madhupratap and Haridas, 1990; Jagadeesan et al., 2013).

From the principal component analyses, it was understood that zooplankton diversity was significantly different from season to season and principally, the zooplankton structure and its dynamics in Gulf of Mannar was structured by seasonal current patterns.

\section{Conclusions}

From the results of PCA analyses, it was found that Temora turbinata is an opportunistic species in to northern Gulf of Mannar. Further, PCA revealed that zooplankton diversity was significantly different among studied seasons and principally, the zooplankton abundance and its dynamics in Gulf of Mannar was structured by seasonal current patterns. The factor loadings of zooplankton for different seasons in Tiruchendur coastal water (GOM) was different from the southwest coast of India, particularly, routine and opportunistic species were found within the positive and negative factors. The copepods Acrocalanus gracilis and Acartia erythrea were dominant in summer and southwest monsoon due to the rainfall and freshwater discharge during the summer season; however, these species were replaced by Temora turbinata during northeast monsoon season.

\section{References}

Alcaraz M, Calbet A, Estrada M, Marrase C, Saiz E, Trepat I (2007). Physical control of zooplankton communities in the Catalan Sea. Progress in Oceanography 74:294312.

Atkinson A (1996). Subantarctic copepods in an oceanic, low chlorophyll environment: ciliate predation, low food selectivity and impact on prey populations. Marine Ecology Progress Series 130:8596.

Beaugrand G (2009). Decadal changes in climate and ecosystems in the North Atlantic Ocean and adjacent seas. Deep Sea Research II: Topical Studies in Oceanography 56:656-673,

Hammer Ø, Harper DAT, Ryan PD (2001). Paleontological Statistics Software: package for education and data analyses. Palaeontologia Electronica

Jacob RM, Ramachandran Nair K, Vasanthakumar R (1981). Zooplankton in relation to hydrography and pelagic fisheries in the inshore waters of Vizhinjam, Trivandrum. Journal of Marine Biological Association of India 23(1-2):62-76.

Jagadeesan L, Jyothibabu R, Anjushaa A, Arya P, Mohana NV, Madhua KR, Muraleedharana Sudheesh K (2013). Ocean currents structuring the mesozooplankton in the Gulf of Mannar and the 
160

Palk Bay, southeast coast of India. Progress in Oceanography 110:27-48.

Jose JJ, Lipton AP, Lincy Alex, Udayakumar P, Rajesh BR, Miranda MTP (2012). Observation of marine copepod-appendicularian naturally changing concentrations along southeast coast of India. Notulae Scientia Biologicae 4(4):20-26.

Jyothibabu R, Mohan AP, Jagadeesan L, Anjusha A, Muraleedharan KR, Lallu KR, Kiran K, Ullas N (2013). Ecology and trophic preference of picoplankton and nanoplankton in the Gulf of Mannar and the Palk Bay, southeast coast of India. Journal of Marine System 111(112):29-44.

Kleppel GS, Holliday DV, Pieper RE (1991). Trophic interactions between copepods and microplankton: a question about the role of diatoms. Limnology and Oceanography 36(1):172-178.

Lawrence D, Valiela I, Tomasky G (2004). Estuarine calanoid copepod abundance in relation to season, salinity, and land-derived nitrogen loading, Waquoit Bay, MA. Estuarine, Coastal and Shelf Science 61:547-557.

Levinsen H, Turner JT, Nielsen TG, Hansen BW (2000). On the trophic coupling between protists and copepods in arctic marine ecosystems. Marine Ecology Progress Series 204:65-77.

Madhupratap M (1987). Status and strategy zooplankton of tropical estuaries: a review. Bulletin of Plankton Society of Japan 34:65-81.

Madhupratap M, Gauns M, Ramaiah N, Kumar SP, Muraleedharan PM, De Sousa SN, Sardessai S, Muraleedharan U (2003). Biogeochemistry of Bay of Bengal: physical, chemical and primary productivity characteristics of the central and western Bay of Bengal during summer monsoon 2001. Deep-Sea Research II 50:881-886.

Madhupratap M, Haridas P (1990). Zooplankton, especially calanoid copepods, in the upper $1000 \mathrm{~m}$ of the southeast Arabian Sea. Journal of Plankton Research 12:305-321.
Madhupratap M, Parulekar AH (1993). Environmental impacts on aquatic and terrestrial habitats. Estuarine Biology Management 215226.

Marques SC, Pardal MA, Pereira MJ, Goncalves F, Marques JC, Azeiteiro UM (2007). Zooplankton distribution and dynamics in a temperate shallow estuary. Hydrobiologia 587:213-223.

Padmakumar KB (2010). Algal blooms and zooplankton standing crop along the southwest coast of India. $\mathrm{PhD}$ thesis, Department of Marine Biology, Microbiology and Biochemistry, School of Marine Sciences, Cochin University of Science and Technology.

Pershing AJ, Greene CH, Jossi JW, Brien LO, Jon KT, Brodziak and Barban AB (2005). Inter decadal variability in the Gulf of Maine zooplankton community with potential impacts on fish recruitment. ICES Journal of Marine Science 62:1511-1523.

Pierce RW, Turner JT (1992). Ecology of planktonic ciliates in marine food webs. Review in Aquatic Science 6:139-181.

Roemmich D, Mcgowan J (1995). Climatic warming and the decline of zooplankton in the California current. Science 267:1324-1326.

Selvin Pitchaikani J, Lipton AP (2015). Seasonal variation of zooplankton and pelagic fish catch in the fishing grounds off Tiruchendur coast, Gulf of Mannar, India. Ecohydrology and Hydrobiology 15:89-100.

Udayakumar P, Abhilash PP, Ouseph PP (2009). Assessment of water quality using Principal Component Analysis-A case study of the Mangalore Coastal Region, India. Journal of Environmental Science and Engineering 51(3):179-186.

Verity PG, Smetacek V (1996). Organism life cycles, predation, and the structure of marine pelagic ecosystems. Marine Ecology Progress Series 130:277-293. 